\title{
Pancasila Philosophy's View on Capital Punishment for Narcotics and Psychotropic Crimes in Indonesia
}

\author{
Eko Supriadi ${ }^{*}$, Syaiful Bakhri ${ }^{2}$, Sultan $^{3}$ \\ ${ }^{1}$ Doctorate Student of Faculty of Law As-Syafi'iyah Islamic University Jakarta, Indonesia \\ ${ }^{2}$ Faculty of Law As-Syafi'iyah Islamic University Jakarta, Indonesia \\ ${ }^{3}$ Faculty of Law As-Syafi'iyah Islamic University Jakarta, Indonesia
}

DOI: $\underline{10.36348 / \mathrm{sjhss} .2020 . \mathrm{v} 05 \mathrm{i} 08.005}$

| Received: 16.08.2020 | Accepted: 24.08.2020 | Published: 26.08.2020

*Corresponding author: Eko Supriadi

\section{Abstract}

Capital Punishment for illegal narcotics traffickers is indeed needed to reduce the crime in the community, even though the polemic in the enforcement of this punishment still arises because it is closely related to human rights enforcement. This research intends to examine weaknesses in the imposition of Capital Punishment based the view of Pancasila philosophy as well as the ideal construction of the Capital Punishment regulation in narcotics and psychotropic offenses based on Pancasila values. The type of writing used in this research is normative legal research method. The method of normative legal research is legal research that places law as a norm system building. The results show that capital punishment can be accounted for in the Pancasila state which is manifested as individual protection as well as protecting society for the creation of justice and legal truth based on the almighty God. The Capital Punishment, from the perspective of Pancasila, is seen as one unity. Pancasila must be the basis for seeing the Capital Punishment as In its implementation, the Capital Punishment for narcotics and psychotropic offenses still has weaknesses therefore it need an ideal construction of the regulation of the Capital Punishment in narcotics and psychotropic offenses based on the values of Pancasila is carried out with due regard to the main crime. With this reconstruction, The Capital Punishment will be a special punishment that can be applied carefully, selectively and specifically in dangerous cases as it must be determined unanimously by the panel of judges first.

Keywords: Pancasila Philosophy, Capital Punishment, Narcotics Crime.

Copyright @ 2020: This is an open-access article distributed under the terms of the Creative Commons Attribution license which permits unrestricted use, distribution, and reproduction in any medium for non-commercial use (NonCommercial, or CC-BY-NC) provided the original author and source are credited.

\section{INTRODUCTION}

In Indonesia, Altough the legislative provisions regulating the issue of narcotics have already been drafted and enforced, the crimes related to narcotics are still cannot be mitigated as in some cases altough many dealers and narcotics dealers have been caught and receive heavy sanctions, yet other perpetrator in the community seem to ignore it and even more inclined to expand their area of operation [1].

Drug abuse is closely related to illicit trafficking as part of the world of international crime. The illicit trafficking mafia supplies drugs, so that people become dependent, so the supply increases. There is a relationship between the dealer / dealer and the victim. Victims find it difficult to escape from them, and sometimes they even become involved in illicit trafficking, because of their increasing need for narcotics.
Law enforcement against the crime of Narcotics, has been carried out by law enforcement officials and there have been many judges' decisions regarding the Narcotics crime. Thus, it is hoped that law enforcement can become an antidote factor against the spread of illicit trafficking and the abuse of narcotics. But in reality, the more intensive law enforcement is carried out, the trafficking and abuse of narcotics also follows in number. Law Number 35 of 2009 concerning Narcotics as the legal basis for the provisions of the laws governing narcotics issues has been drafted and enforced, however, crimes related to narcotics still cannot be mitigated.

The abuse of narcotics as referred to in Law Number 35 of 2009 concerning Narcotics provides contains a fairly severe criminal sanction, however, in reality the perpetrators of crime are increasing, and for convicted persons in reality are not deterred and there is 
a tendency to repeat it again. This can be caused by a factor imposing punishment by the judge which does not have a deterrent effect on the perpetrators.

In general, the imposition of crimes by judges tends to prioritize criminal sanctions if they are commensurate with the perpetrators' actions, with the aim that the perpetrators do not repeat their actions. This paradigm is certainly not suitable when dealing with crimes related to narcotics abuse, because in narcotics abuse the perpetrator (narcotic addict) is not only positioned as a criminal, but also as a victim. This is because narcotics addicts are "self-victimizing victims", because narcotics addicts suffer from addiction syndromes as a result of self-abusing themselves to narcotics.

According to Article 54 of Law No. 35 of 2009 on Narcotics, it states that narcotics addicts and victims of narcotics abuse are required to undergo medical rehabilitation and social rehabilitation. Rehabilitation of narcotic addicts is a treatment process to free addicts from dependence, and the period of undergoing rehabilitation is calculated as a period of serving a sentence.

Law enforcement in Indonesia has been running in accordance with the prevailing laws and regulations. On the other hand, problems were found in the handling of criminal cases of drug abuse as happened in Tangerang, Banten, namely the Panel of Judges at the Tangerang District Court in the Tangerang District Court Decision No 462 / Pid.Sus / 2016 / PN.Tng which sentenced the defendant who was proven legally. legally and convincingly guilty of committing narcotics, psychotropic and health crimes with a life sentence.

Furthermore, at the Banten High Court level, the Panel of Judges at the Banten High Court through Decision No 98 / PID / 2016 / PT.BTN changed the decision to a death sentence. Furthermore, this case after being brought to the cassation level through the cassation decision at the Supreme Court level No 2759 K / PID.SUS / 2016 stipulated a decision in the form of rejecting the petition for cassation from the petitioner or the defendant so that the defendant had to undergo the death sentence. This decision has received a lot of debate from the human rights protection and anti-drug circles.

Seeing the above problems, the authors feel that it is interesting to examine it in a study using the Pancasila philosophy's View analysis in which the authors use to discuss the following issues :

1. What are the legal weaknesses in the execution of the Capital Punishment in narcotics and psychotropic offenses in Indonesia currently?

2. What is the ideal construction of the regulation of Capital Punishment in narcotics and psychotropic offenses in Indonesia based on the Pancasila philosophy's View?

\section{METHOD OF RESEARCH}

The paradigm that is used in the research this is the paradigm of constructivism which is the antithesis of the understanding that lay observation and objectivity in finding a reality or science knowledge [2]. Paradigm also looked at the science of social as an analysis of systematic against Socially Meaningful Action through observation directly and in detail to the problem analyzed.

The research type used in writing this paper is a qualitative research. Writing aims to provide a description of a society or a certain group of people or a description of a symptom or between two or more symptoms.

Approach (approach) the research is to use the approach of Normative-Juridical [3], which is based on the norms of law and the theory of the existing legal enforceability of a law viewpoint as interpretation.

As for the source of research used in this study are:

1. Primary Data, is data obtained from information obtained from literature review derived from the existing regulation, credible news and data obtained from interted parties.

2. Secondary Data, is an indirect source that is able to provide additional and reinforcement of research data. Sources of secondary data in the form of: Primary Legal Material and Secondary Legal Materials and Tertiary Legal Material.

In this study, researchers uses data collection techniques, namely literature study, interviews and documentation. In this study, the researcher is a key instrument that is the researcher himself who plans, collects, and interprets the data [4].

\section{RESEARCH RESULT AND DISCUSSION Legal Weaknesses in the Execution of the Capital Punishment in Narcotics and Psychotropic Offenses in Indonesia Currently \\ In the basic of criminology, a punishment will} be effective if the sentence is consistently applied to punish the perpetrator of the crime so that there is a significant deterrent effect to prevent the individual from committing a crime. The Capital Punishment imposed for narcotics crimes in Indonesia is unlikely to have a significant deterrent effect. As stated by Beccaria [5] in Deterrence theory that in order to prevent the perpetrator of a crime from repeating the crime he committed, the punishment for the perpetrator of the crime must be consistently given and the sentence does not provide a cruel example for society. The Capital Punishment given to perpetrators of narcotics crimes in Indonesia tends not to be 
consistently given to the perpetrators and this Capital Punishment is also considered a cruel punishment.

In the theory of deterrence it is also stated that the punishment must be given quickly to the perpetrator of the crime to produce a strong deterrence effect, but this cannot be done in the current criminal system because of the protected rights of the convicted convict. Like the Capital Punishment, the execution of this sentence cannot be carried out quickly against the convicted person, because of the rights that the convict has. This shows that the Capital Punishment is doubtfully able to produce a deterrent effect because it takes a long time to carry out the execution and it is impossible to accelerate the execution of the execution due to the existence of regulations that aim to protect the rights of the convict himself.

The theory of deterrence also explains that punishment must have certainty to provide a strong deterrent effect. The death sentence given to drug offenders in Indonesia tends to be uncertain because of the clemency that the president can give. The granting of clemency is also the right of the convict himself and the right to clemency is also regulated in the Law.

It is evident that the implementation of the Capital Punishment which aims to control narcotics crimes in Indonesia is ineffective and in its implementation the Indonesian government tends to ignore the rights possessed by narcotics convicts. The Indonesian government tends to not think long enough to solve the problem of narcotics crimes that are rife in Indonesia. The government tends to only think that if these narcotics dealers are punished by death, the crime rate of narcotics will automatically decrease, meaning that the public will be afraid because of the severity of the punishment, which will produce a deterrent effect. However, the government's opinion is wrong.

According to the author, whether or not the effects of deterrence are functioning in a punishment depend on the risk of detecting the violation committed. If violations are consistently identified and punished, the resulting deterrent effect will be stronger. Thus it can be concluded that the effect of deterrent does not depend on the severity or lightness of a punishment.

According to the results of a study conducted by The Commission for Disappeared and Victims of Violence/ KontraS [6], the implementation of the Capital Punishment in Indonesia is ineffective because based on research conducted by KontraS, Capital Punishment has failed to provide a deterrent effect on criminals. Research conducted by KontraS is related to the increasing number of narcotics crimes even though the Capital Punishment has been imposed. Evidence that the Capital Punishment does not provide a deterrent effect, especially for narcotics crimes, is that factories producing methamphetamines and MDMA (ecstasy) are still found in the Cikande area, which is 60 kilometers from the city of Jakarta. It is estimated that the profits will be 100 billion dollars.

The National Narcotics Agency (BNN) stated that the abuse and distribution of narcotics in the community has shown an increase with the spread of victims due to drugs. Head of the National Narcotics Agency (BNN) Heru Winarko said the trend of increasing use of narcotics was increasing with victims ranging from children to state officials. The victims spread to include children, adolescents, the young generation, civil servants, members of the TNI and Polri, regional heads, members of the legislature, to the household environment.

In Indonesia, currently there are more than 140 people have been charged with trafficking in narcotics and sentenced to death since 2014 [7]. Most of those sentenced to death for narcotics cases are foreign nationals. Data provided by the Directorate General of PAS in July 2019 recorded that 70 of the 268 people sentenced to death were foreign-nationality. Referring to BNN data in 2018, the prevalence of drug abuse among students in 13 provincial capitals in Indonesia reached 3.2 percent or the equivalent of 2.29 million people. Meanwhile, in 2017, the National Narcotics Agency recorded the prevalence rate of narcotics abuse at 1.77 percent or the equivalent of $3,376,115$ people in the 10-59 years age range. Drug abuse is increasing following the increase of the use of internet technology in relation to illicit narcotics trafficking. This and in addition to, the value of transactions and types traded are also increased.

In controlling narcotics crimes in Indonesia, the Capital Punishment is used as the basis for the toughest punishment policy for narcotics crimes by the government in the hope that this punishment for narcotics crimes can significantly reduce the number of narcotics crimes. But in reality, even though the Capital Punishment has been implemented, there is no significant change in the number of narcotics crimes, instead what has happened is an increase in the number of narcotics crimes as reported by the National Narcotics Agency mentioned above.

Changes and developments in world society have brought us to the problem of Capital Punishment in the context of the 21 st century world. Long ago, everything seemed simple, like the formula for" life for life" In such a social context, the Capital Punishment was not much of a problem. now the situation can no longer be understood in such a simple way. The development of civilization has led to a very delicate civilization, especially when talking about things related to humans. Many teachings, doctrines, institutions were created to safeguard human glory. how many people were sentenced to death, hanged, beheaded, slashed by guillotines, shot and injected. 
Famous people were no exception from executions, from King Louis XVI, Empress Marie Antoinette, Robespierre, Russian Emperor Nicholas, to Herman Goring and a number of high-ranking Nazi Germany at the end of the Second World War and most recently Saddam Housein in where the author argues that the Capital Punishment has not been well extinguished until today's age. In order to eradicate corruption in his country, a Chinese leader does not hesitate to order one hundred coffins for corruptors, including one for the leader when he commits the crime. Ages rotate and history enters a new era of civilization. Human civilization is getting richer with various considerations, thoughts and the presence of institutions that want to glorify human life. There are human rights, there are conventions of the United Nations (UN) on the prohibition of cruel and degrading punishment [8].

Some of the nations of the world have imposed the Capital Punishment and some have abolished it. Even in a federal state, the states also apply different punitive policies. There have been movements for abolition or abolition of capital punishment. The United Nations Convention on Human Rights in Vienna in 1993 also still respects the rule of law of the countries in the world to determine the political law they want to follow. Even if a country determines the punishment, including politics for the Capital Punishment, the world must respect the laws of that country. The 1996 UN Resolution is also still tolerant towards countries that still carry the threat of the Capital Punishment in their positive laws. The world body is just a message. On 11 December 1977 in Stockholm, Amnesty International called for the abolition of the Capital Punishment worldwide. Until 1979 there were still 117 countries that stated the Capital Punishment. At the Crime Prevention and Criminals Development conference in Caracas, August 1980, it was noted that at least 860 people had been sentenced to death. However, to reduce physical suffering, several attempts have been made for its execution, namely through the electric chair, gas chamber, firing squad, and other efforts, namely delaying the execution of the Capital Punishment or amending the Capital Punishment with life imprisonment.

Based on the foregoing, the authors draw a conclusion that the weaknesses of the execution of the Capital Punishment against the perpetrators of illegal narcotics trafficking are, among others:

a) There is no sufficiently strong scientific evidence regarding the effectiveness of the Capital Punishment in narcotics and psychotropic offenses at this time related to the deterrence effect as one of the purposes of crime, accuracy and justice for this Capital Punishment decision, concern about executing the wrong person, and considered inhuman.

b) The existence of Optional Protocol II to the International Convention on Civil and Political
Rights (ICCPR) which advocates the abolition of the Capital Punishment.

c) In relation to the a quo petition, it seems clear that almost all of the Petitioners' arguments are built on arguments that start solely from the perspective of the right to life of the person sentenced to death.

d) In executing the convict of the crime of narcotics and psychotropic offenses, it cannot be carried out quickly because they have rights, one of which is filing for clemency. The convicts have the right to apply for clemency to the president to get interdiction by replacing the Capital Punishment he received with another alternative law, namely life imprisonment.

e) The level of consistency of law enforcers and the government is not serious enough to respond to and be responsive to decisions and / or policies made by the panel of judges in deciding cases, especially drug offense cases, both in the first, high, cassation and judicial review (PK) levels so that the verdict is truly can be accepted and implemented properly without any elements that can weaken law enforcement in Indonesia and pay attention to the provisions of the 1945 Constitution of the Republic of Indonesia and Human Rights.

\section{Ideal Construction of The Regulation of Capital Punishment in Narcotics and Psychotropic Offenses in Indonesia Based on The Pancasila Philosophy's View}

Capital Punishment is a penalty that is old in age, but young in the news. The Capital Punishment has always been a matter of debate in various circles regarding the pros and cons of capital punishment. Even in the context of a global perspective, there are still pros and cons views regarding the existence of capital punishment and its execution. Data compiled by Barda Nawawi Arief [9] shows the balance between the group against the Capital Punishment (Abolitionist) and the pro-Capital Punishment group (Retensionist), so that there are 98 countries from the abolitionist group that still use the Capital Punishment as an exceptional punishment, for special circumstances. So there are still 109 countries that still recognize the existence of capital punishment, and there are those that do not use or postpone the imposition of capital punishment for quite a long time.

The conflict in the imposition of the Capital Punishment is basically divided into two sides, namely the abolitionists and the retentionists. Abolitionists base their argument on several reasons. First, the Capital Punishment is a form of punishment that is degrading to human dignity and contrary to human rights. On the basis of this argument, many countries have abolished the Capital Punishment in their criminal justice system. Until now, 97 countries have abolished the Capital Punishment. European Union member states are 
prohibited from applying the Capital Punishment under Article 2 of the Charter of Fundamental Rights of the European Union of 2000 [10].

The UN General Assembly in 2007, 2008, and 2010 adopted non-binding resolutions calling for a global moratorium on the Capital Punishment. The Optional Protocol II to the International Covenant on Civil and Political Rights / ICCPR finally prohibits the use of the Capital Punishment by the parties concerned. The basis for the next argument put forward by the abolitionist group is the constitutionality of the Capital Punishment. Abolitionists in the United States, for example, oppose the Capital Punishment because it contravenes with the 8th Amendment of the United States Constitution.

The basis of constitutional argumentation has also been used by abolitionists in Indonesia. In 2007, two Indonesian citizens who were sentenced to death in drug cases, namely Edith Sianturi and Rani Andriani, and three Australian members of the Bali Nine, namely Myuran Sukumaran, Andrew Chan, and Scott Rush, submitted a request for constitutional review to the Constitutional Court on the Capital Punishment article in the Law Law Number 22 Year 1997 concerning Narcotics.

The petitioner's attorney argued that the Capital Punishment article Law no. 22/1997 contradicts Article 28A Amendment II of the 1945 Constitution. However, the petition of the petitioners was rejected by the panel of judges of the Constitutional Court which in essence stated that the Capital Punishment for serious crimes constitutes a form of limiting human rights.

Abolitionists also argue that retentionists believe the Capital Punishment will have a deterrent effect and, therefore, will reduce the crime rate, especially drug-related crimes however, there is no conclusive scientific evidence that proves a positive correlation between the Capital Punishment and the reduction in drug crime rates.

In contrast to abolitionists, retentionists are no less bitter in arguing in favor of the Capital Punishment. The main reason is that the Capital Punishment has a deterrent effect on potential criminals of drug crimes. If they realize that they will be sentenced to death, such criminals will at least think a thousand times before committing a drug crime.

The facts prove, that when compared to developed countries that do not implement the Capital Punishment, Saudi Arabia, which applies Islamic law and the Capital Punishment, has a low crime rate. Based on data from the United Nations Office on Drugs and Crime in 2012, for example, the murder crime rate was only 1.0 per 100 thousand people. Compare with
Finland which amounted to 2.2; Belgium 1.7; and Russia 10.2.

Retentionists also reject the opinion of abolitionist groups that the Capital Punishment (for drug criminals) is against humanity. On the contrary, they think that drug crime is an extraordinary crime that defames humanity. Drug crime is a crime against humanity that takes the right to life of not only one person, but many people. Retentionists argue that the Capital Punishment for drug criminals does not violate the constitution as stated by the Constitutional Court.

Judicial practice has always been the hope of people who seek justice, in presenting evidence in a variety of activities. Proof always provides a very useful meaning for the search for essential truth, in fighting for the legal rights of society. The importance of this proof is very comprehensive and universal, and is the main basis for legal governance of events and legal conditions, which of course have resulted in law in a concrete sense. Thus, attention to proof must receive more attention by the state, so that every citizen can be calm and happy, in achieving dreams and aspirations, to become a just, prosperous and happy society.

In the evidence-proving process, it begins with determining the extent of the evidence. This means that the judge first determines what facts are relevant to the final decision. After the judge has examined according to his conviction which facts he considers sufficiently certain. Then he looks at which facts still need to be proven. This is all what is meant by the extent of evidence. It can be predicted that in practice the facts will first be put forward in the trial process by the parties.

The author quotes what Muladi and Barda Nawawi Arief [11] have said that in its development, the attention of the criminal justice system on Capital Punishment seems quite serious. The criminal justice system is not only seen as a crime prevention system, but is seen as a "social problem" similar to the crime itself. It is said so because in addition to the fact that crime continues to increase, which can be seen as an indicator of the ineffectiveness of the criminal justice system, it is also because the criminal justice system itself can in certain cases be seen as a criminogenous and victimogenic factor.

The criminal justice system as a criminogen and victimogen factor means that the criminal justice system is an indirect source of criminal acts and victims of criminal acts. It can be seen that the operation of the criminal justice system which consists of the subsystem of the police, prosecutors, courts and prisons as well as the community itself is a series of criminal justice processes that must be well coordinated. If not, then the criminal justice system itself is one of the 
factors in the emergence of criminal acts and the emergence of victims of criminal acts.

In connection to what is stated above so that there is justice in accordance with the value of the Pancasila philosophy, it is necessary to have a legal reconstruction of the provisions of the Capital Punishment for narcotics criminals.

The ideal construction of the Capital Punishment regulation in narcotics and psychotropic offenses as referred to by the author must be based on the values of the Almighty God, must also be sourced from other Pancasila values which include, First, human values, second national values, third populist, and Fourth Social Justice. When the Pancasila values have been fulfilled and are in accordance with the ideals of the law and the ideals of the country itself, the Capital Punishment can be adjusted to the values of Pancasila for the Capital Punishment for narcotics crimes. The ideal construction of the Capital Punishment regulation in narcotics and psychotropic offenses based on Pancasila values is as follows: The Draft Law on the Criminal Code still adopts the Capital Punishment, the Capital Punishment is still necessary but not the main crime. The Capital Punishment must be a special punishment that is applied carefully, selectively and specifically in dangerous cases and must be determined unanimously by the panel of judges. The correct understanding of the imposition of the Capital Punishment in relation to extraordinary crimes such as narcotics crimes must be seen as an effort to protect the "right to life" of many people.

The Capital Punishment as regulated in Law Number 35 of 2009 concerning Narcotics must be viewed in the context of protecting the right to life of the wider community. In fact, narcotics criminals (drug dealers, users and international narcotics syndicates) who are caught by the authorities and then sentenced to death by the court must be seen as people who endanger the "right to life" of others or society. The law must protect the interests of many people, who are the targets of narcotics transactions. Imposition of punishment by the judge in the future refers to "let punishment fit the criminal" with predetermined parameters. The concept of interchangeability of punishment in principle is needed to overcome an inflexible and uncreative criminal justice system. In connection with its current implementation, which is based on applicable material and formal law, namely, a special law on capital punishment should be drafted immediately to complement the provisions of the current Criminal Code before the Draft Criminal Code becomes positive law in Indonesia in relation to the need to reshuffle which actions are punishable by death by re-setting the parameters of the punishment (anchoring the penalty scale) so that they can be rearranged based on the level of crime (gravity of crimes).

\section{CONCLUSION}

1. The weakness of the implementation of the Capital Punishment against the perpetrators of illegal narcotics trafficking are the absence of sufficiently strong scientific evidence regarding the effectiveness of the Capital Punishment in offenses against narcotics and psychotropics at this time, the existence of Optional Protocol II to the International Convention on Civil and Political Rights (ICCPR) which recommends the abolition of sentences death, almost all of the Petitioners' arguments are built on arguments that start solely from the perspective of the right to life of the person sentenced to death, the execution of those convicted of narcotics and psychotropic offenses cannot be carried out quickly because of the one of them is the filing of clemency, and lastly, the level of consistency of law enforcers and the government is not serious enough to respond to and respond to decisions and / or policies related to drug cases.

2. Capital Punishment can be accounted for in the Pancasila Philosophy's View in which is manifested as individual protection as well as protecting society for the creation of justice and legal truth based on Almighty God. The Capital Punishment, from the perspective of Pancasila, is seen as one unit. Pancasila must be the basis for seeing the Capital Punishment. In its implementation, the Capital Punishment for narcotics and psychotropic offenses also has weaknesses so that to overcome this it is necessary to construct a new capital punishment regulation in offenses for narcotics and psychotropic drugs based on the values of Pancasila, while still paying attention to the main crime. The Capital Punishment must be a special punishment that is applied carefully, selectively and specifically in dangerous cases and must be determined unanimously by the panel of judges.

\section{REFERENCES}

1. Rosyid, M. (2018). Imbas Konsistensi Hukuman Mati pada Hubungan Bilateral dalam Kasus Narkoba. YUDISIA: Jurnal Pemikiran Hukum dan Hukum Islam. 8. 255. 10.21043/yudisia.v8i2.3239.

2. Faisal. (2010). Menerobos Positivisme Hukum, Rangkang Education, Yogyakarta.

3. Johnny, I. (2005). Teori dan Metodologi Penelitian Hukum Normatif, Bayumedia, Surabaya.

4. Moleong, L. (2002). Metode Penelitian Kualitatif, PT Remaja Rosdakarya, Bandung.

5. Beccaria, B., \& Nawawi, A. (2011). Pemahaman Hukum Pidana dalam Perspektif Kajian Perbandingan, Bandung: Citra Aditya Bakti, 290.

6. Kontra, S. (2013). Capital Punishment in Indonesia: Update 2012-2013. Jakarta. 
7. Kompas.com. (2019). BNN Sebut Penyalahgunaan dan Peredaran Narkotika Semakin Meningkat, https://nasional.kompas.com/read/2019/06/26/114 21691/bnn-sebut-enyalahgunaan-dan-peredarannarkotika-semakin-meningkat. Accessed on 2 January 2020.

8. Purwodirekso, M. (2015). Efektivitas Dan Kecenderungan Penggunaan Hukuman Mati. AlRisalah. 5. 1-18. 10.34005/alrisalah.v5i1.386.
9. Barda, N. A. (1984). Kebijakan Kriminal. Faculty of Law, Universitas Diponegoro, Semarang.

10. Iriani, D. (2016). Kejahatan Narkoba: Penanggulangan, Pencegahan dan Penerapan Hukuman Mati. Justicia Islamica. 12. 10.21154/justicia.v12i2.331.

11. Muladi, B., \& Nawawi, A. (2005). Pidana dan Pemidanaan dalam Teori-Teori dan Kebijakan Pidana, Third Edition, Bandung: Alumni. 